\title{
Management of Parenting Activities in Forming Character of Early Childhood
}

\author{
Hefniy $^{1 凶}$, Anggie Nadia Dinihari ${ }^{2}$, Fathor Rozi $^{3}$, Nur Aini $^{4}$, Afifah Tunnaja ${ }^{4}$ \\ Manajeman Pendidikan Islam, Universitas Nurul Jadid, Paiton, Probolinggo, Indonesia(1) \\ Keguruan dan Ilmu Pendidikan, Universitas Islam Negeri Sultan Aji Muhammad Idris, \\ Samarinda, Indonesia(2); Pendidikan Agama Islam, Universitas Nurul Jadid, Paiton, \\ Probolinggo, Indonesia(3); Pendidikan Islam Anak Usia Dini, Universitas Nurul Jadid, Paiton, \\ Probolinggo, Indonesia $(4)$ \\ DOI: 10.31004/obsesi.v6i4.2065
}

\begin{abstract}
This study aims to analyze parenting activities in shaping the character of early childhood at Taman Posyandu Anak Salih. The research method used is a qualitative case study type. Researchers conducted interviews with principals and teachers at the institution. The study results indicate that the formation of children's character requires a continuous and consistent process, both when the child is in the family environment, school environment, and community environment. Schools in approaching parents through parenting activities are carried out through; 1) planning includes determining the time, place of materials, and media needed in parenting activities; 2 ) implementation, namely the form of parental meetings or parent classes by prioritizing the discussion and sharing process; 3) evaluation in the parenting program using question and answer according to the material that has been conveyed with parents and meetings regarding ongoing programs conducted by educators and managers so that parents become partners in the formation of children's character.
\end{abstract}

Keywords: Management, Parenting; Character, Early Childhood , Parents

\begin{abstract}
Abstrak
Penelitian ini bertujuan untuk menganalisis tentang kegiatan parenting dalam membentuk karakter anak usia dini di Taman Posyandu Anak Shalih. Metode penelitian yang digunakan adalah kualitatif jenis studi kasus.Peneliti melakukan interview terhadap kepala sekolah dan guru di lembaga tersebut. Hasil penelitian menunjukkan bahwa dalam pembentukan karakter anak diperlukan proses yang berkesinambungan dan konsisten, baik ketika anak berada dalam lingkungan keluarga, lingkungan sekolah, maupun lingkungan masyarakat. Sekolah dalam melakukan pendekatan kepada orang tua melalui kegiatan parenting dilakukan melalui; 1) perencanaan meliputi penetapan waktu, tempat materi dan media yang dibutuhkan dalam kegiatan parenting; 2) pelaksanaan yaitu bentuk pertemuan orangtua atau kelas orangtua dengan mengedepankan proses diskusi dan sharing; 3) evaluasi dalam program parenting dengan cara tanya jawab sesuai dengan materi yang telah disampaikan bersama orangtua dan rapat mengenai program yang telah berjalan yang dilakukan pendidik dan pengelola, sehingga orang tua benar-benar menjadi mitra dalam dalam pembentukan karakter anak.
\end{abstract}

Kata Kunci: Manajemen, Parenting; Karakter, Anak Usia Dini, Orang Tua

Copyright (c) 2022 Hefniy, et al.

$\triangle$ Corresponding author :

Email Address : hefniyrz@gmail.com (Paiton, Probolinggo, JawaTimur, Indonesia)

Received 14 November 2021, Accepted 28 December 2021, Published 20 February 2022 


\section{INTRODUCTION}

The formation of a child's character is not born just like that; there is a process he goes through to become a character that is inherent in a child (Almuhajir, 2021; Atika et al., 2021). Starting from the child being born and growing up to become an adult in the family environment, hanging out with friends in-game groups, schools, to the community (Prasanti \& Fitrianti, 2018; Iltiqoiyah, 2020). The inculcation of character values is an essential target in the early childhood learning process (Zamroni et al., 2021; Rozi \& Maulidiya, 2022). Children from an early age have been taught and trained to instill character values such as responsibility, honesty, independence, etc. The inculcation of character and moral values from an early age must refer to aspects of child development (Ramdhani, Yuliastri, Sari, \& Hasriah, 2019).

Character planting should indeed be given as early as possible to children (Baharun, 2017). Early age is a critical period for forming one's character. Failure to cultivate character from an early age will develop a problematic personality in later adulthood because character cultivation in early childhood is a fundamental process that forms the basis of human personality (Tanto et al., 2019). Good habits are needed in daily life at school and home in building character (Maryam, 2018; Muali et al., 2021). The role of parents in educating children is to provide primary education, basic attitudes, and skills, such as religious education, personality, manners, aesthetics, affection, a sense of security, the basics for complying with regulations, and instilling habits (Cahyono et al., 2018; Munif et al., 2021). In addition, the family's responsibility is to instill values and behavior through what is taught in school. In other words, there is a link between what is taught at home and what is taught in school.

It is so essential to build a good relationship between school and parents. (Arif \& Pratama, 2019), considering that education and care at home also play a vital role in the formation of a child's character, if a child gets good character education at school as well as good habits at home, the child will have a good feeling at a later stage (Atika et al., 2021; Almuhajir, 2021). Because even though schools can increase the initial understanding of their students when they are at school, the good attitudes possessed by these children will slowly disappear if the values taught at the school do not get support from the home environment. Therefore, the pious Children's Posyandu Park must create good collaboration with families, which in this case are parents, in strengthening children's character. To maximize the role of parents to form and develop a feeling for children, one of them is through parenting education in schools.

The parenting program is carried out to bring together the interests and desires of parents and the school to equalize the perceptions of both parties (Finori, 2019; Jennah, 2019), so that character education in schools can be continued in the family environment so that parents and schools can support each other, strengthen each other, and support each other cooperate (Zulfaizah, 2018; Gultom et al., 2021). The purpose of parenting is to help parents increase awareness that the primary educators for children are parents, assist parents in knowing the process of growth and development of children, and be involved in children's school activities (Umiarso \& Hidayati, 2022). This is by Presidential Regulation of the Republic of Indonesia Number 60 of 2013 that to ensure the fulfillment of the rights of early childhood growth and development, efforts to improve health, nutrition, care, care, protection, welfare, and educational stimulation are carried out simultaneously, systematically, thoroughly, integrated and sustainable (Perpres, 2013).

Parenting activities will be a forum that can benefit all parties, both parents, PAUD, and the government. There are several benefits in implementing parenting: (1) For example, the establishment of cross-sectoral partners, from entrepreneurs related to the development needs of children, government agencies, book publishers, and others. (2) Ensuring that children's rights are met. (3) Increasing parents' confidence in their ability to educate their children.(4) Establishing a harmonious relationship with each family member based on their respective responsibilities. (5) Fostering connections between families in the community 
around educational institutions.(6) The establishment of working partners among fellow parenting members (Ariyati, 2016).

So that parents can gain knowledge of education both in terms of caring for, maintaining, nurturing, educating, and shaping early childhood, Taman Posyandu Anak Shalih holds a parenting program. Through this parenting program, parents will gain knowledge and skills to help young children grow and develop according to their potential through appropriate stimulation. Parenting programs can also increase parents' awareness of the importance of being involved in PAUD programs. Parents cannot simply hand over their children's education to educational institutions. (Fauzi \& BR, 2018). Awareness and active involvement of parents in the PAUD program will support success in shaping children's character.

Many studies on parenting activities in shaping the character of early childhood, for example, in the first study stated that The picture of parenting on the development of children's social behavior is very diverse, as well as social development, in this case, namely playing with peers, cooperation, sharing, completing tasks and getting to know manners and manners. (Junita \& Anhusadar, 2021). Meanwhile, another study stated that, after assisting for six months to managers and teachers, schools already have a routine schedule once every two weeks for parenting activities to parents with parenting material plans that are pretty systematic and structured using a learning approach. adults and by the character of the local community (Mahmudah, 2018; Suharyani et al., 2021). Some state that, Character Building through Parenting Education in Schools, namely: 1) Schools carry out sharing parenting activities with parents and school committees to build joint commitments in children's education 2) Implementation of parenting education through parenting seminars, parent consultation days, lectures religion, madin recitation activities using the ummi method, teacher visits to students' parents' homes 3) The results of achieving character building in schools include a) Students are accustomed to greeting, b) students are polite, c) students show noble character traits, d) students have concern for the environment (Afifah, Maulidi, \& Faza, 2021). Research also states that the implementation of activities provides changes to teachers in the form of being able to design parenting education programs according to the needs of parents/guardians and being committed to implementing parenting education programs at institutions periodically. This kind of coaching activity can be carried out sometimes to maintain and provide information related to early childhood care involving parents or guardians of students (Rahma et al., 2021). Meanwhile, other research also states increasing parental understanding of parenting in early childhood. The response of all stakeholders and educators is excellent (Indarawati, 2021). According to them, parents can take care of their children according to the child's growth and development pattern properly with this parenting activity.

Some of these researchers explained innovation to create good collaboration between teachers and parents in educating their children. Meanwhile, Parenting management in shaping character at Taman Posyandu Anak Salih must be developed to deepen parents' knowledge in guiding and nurturing their children to shape the character of children who are responsible and have good personalities in the future, namely the golden generation.

Based on the explanation of Parenting Activity Management in Shaping Early Childhood Character at Taman Posyandu Anak Salih, it is essential to conduct this research to find out what activities are included in the Shaping Early Childhood Character program. Reviewing the Management of Parenting Activities implemented at Taman Posyandu Anak Salih shows what teachers at school and parents need to do at home to build a good relationship between school and parents, considering education and care at home. Also plays a vital role in the formation of children's character. Because, if a child gets good character education at school and good habits at home, the child will have a good feeling at a later stage. Because even though schools can increase the initial understanding of their students when they are at school, the 
good attitudes possessed by these children will slowly disappear if the values taught at the school do not get support from the home environment.

\section{METHODOLOGY}

This study uses a qualitative approach; the approach was chosen so that researchers can give a complete picture of a phenomenon (Farida, 2014). At the same time, the type of research used by the researcher is a case study because this study examines a specific subject, namely Taman Posyandu Anak Salih, to get an overview of Parenting Activity Management in Shaping Early Childhood Characters at Taman Posyandu Anak Shalih.

As a case study research, the data sources in this study were obtained by conducting interviews and in-depth observations. To support the validity of these observations, the researchers also documented parenting activities at Taman Posyandu Anak Salih, Karanganyar sub-district, Paiton sub-district, Probolinggo district. The informants in this study were the head of the Salih Children's Posyandu Park, the teacher at the Shalih Children's Posyandu Park, and the guardians of the students. The data analysis process in this study can be seen from the figure 1 .

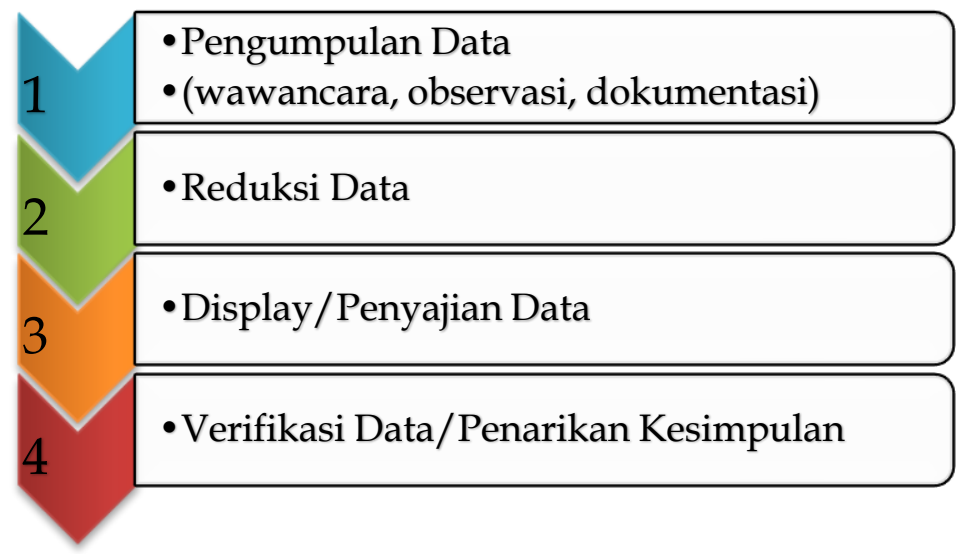

Figure 1 Stages of Data Analysis Techniques

Figure 1 shows the process of the stages of data analysis techniques that begin with collecting data through interviews and observations accompanied by documentation. After all the data has been collected, the researcher reduces the data by sorting and selecting essential and according to the research topic. The reduced information is then presented in the research in a clear, coherent, and systematic way so that it is easy to understand. Finally, the research results that have been given are verified to obtain conclusions.

\section{RESULTS AND DISCUSSION}

Good habits are needed in daily life at school and home in building character. One of the environments responsible for shaping and building character in children is the family. The family environment is where children interact with family members, both direct and indirect interactions. The family atmosphere will affect the development of the child's personality. Children who learn will receive influence from the family in the way their parents educate, the relationship between family members, and the house's atmosphere. Positive experiences and activities that children receive in the family can help them train their moral potential. Therefore, there needs to be good collaboration between schools and families to form and develop a character for early childhood.

\section{Planning for Parenting Activities}

The development of parenting programs is one of the methods in building the character of life that exists amid a global society. Because the quality of family relationships is 
an essential element in building a mutually supportive community. Mistria Harmonis, as the principal, explained that Parenting is routine activity at the Salih Children's Posyandu Park, which is held twice a year and is filled by practicing psychologists or pediatricians. At the same time, the participants are guardians of students because the involvement of parents will be one of the determinants in the success of existing programs in school institutions.

The parenting program, which is one of the programs in strengthening the lives of Indonesian families and society, provides one of the reinforcements in people's lives, especially the development of early childhood, parenting methods, and communication patterns carried out by most people (Akhyadi \& Mulyono, 2018). Meanwhile, Anis Sulalah, as part of the curriculum, explained that in planning the parenting program at Taman Posyandu Anak Salih, one of the implementations of the institutional motto called the "golden triangle", it is said to be a golden triangle because there are three things that determine the success of children in gaining knowledge. Namely the school, students, and parents. So that it is not only schools and students who carry out the learning process, but parents also take part in the learning of their sons and daughters.

The right approach in family education is expected to provide results in strengthening community accessibility to improve the quality of life through family strengthening. Not only using an economic approach but also using an educational approach which is expected to be much more capable of shaping the character of the Indonesian people in the future (Ummah, 2018; Alfina \& Anwar, 2020; Suharyani et al., 2021). Likewise, Ernawati Shalihah, as the class teacher explained that, the parenting program at the Salih Children's Posyandu Park is a program organized by the school and the students' parents. The existence of this program since the beginning of the school's establishment, one of which aims to equalize children's education both at school and at home. Preparation meeting for parenting activities by teachers and guardians can seen on the Figure 2.

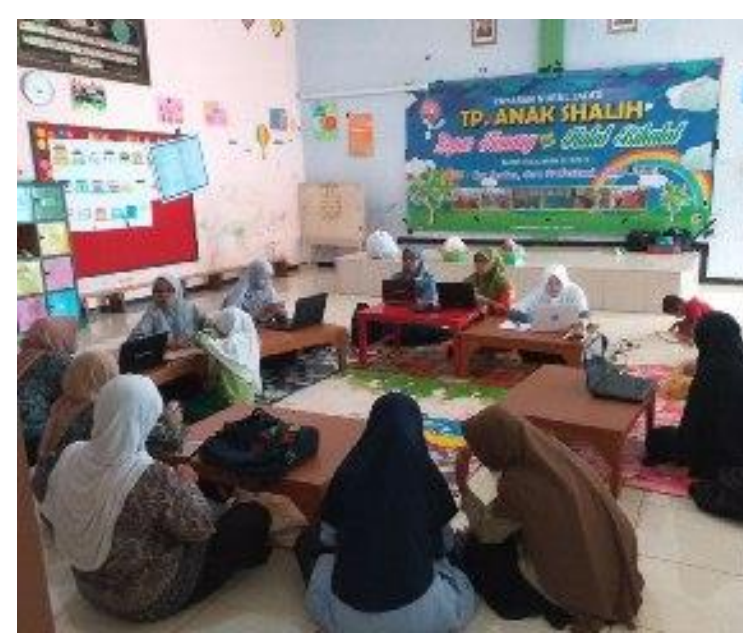

Figure 2 Preparation meeting for parenting activities by teachers and guardians

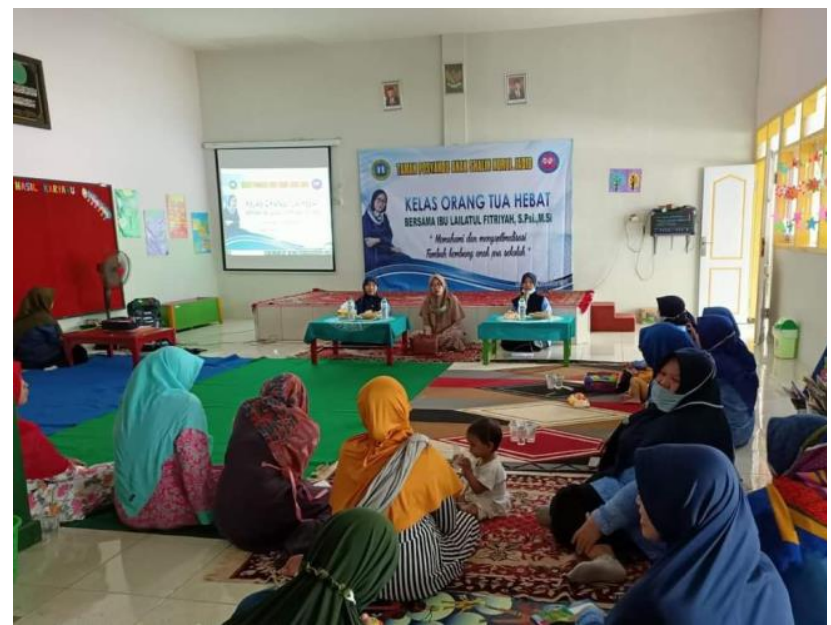

Figure 3. The parenting event occurred at the Taman Posyandu Salih Children's Hall.

In planning the parenting program, the school prioritizes the guardians of students because they are $40 \%$ of the success of this program. Why is that? The role of the guardian of students towards the school is synergy, which means building relationships with each other. Parenting in education involves parents in educational activities that aim to help achieve a home environment to support the growth and development of children and obtain information about health, safety, nutrition, and all matters related to child development. In planning parenting programs, schools determine various activities, ranging from small-scale to large-scale activities. 


\section{Organizing Parenting Programs}

In the process of organizing in an educational institution, a manager determines the division of tasks, authorities, and responsibilities in detail based on their respective parts and fields so that synergistic, cooperative, harmonious, and rhythmic working relationships are integrated into achieving the agreed goals together (Nurmiyanti \& Candra, 2019; Mundiri \& Jannah, 2021). Mistria Harmonis explains that, In carrying out the task of organizing, things that must be considered are providing facilities, equipment, and items needed for the smooth implementation of parenting.

The implementation of this parenting program must be carried out properly because it will affect parents' satisfaction with the relevant school institutions because when parents are satisfied with the online parenting services of school institutions, the trust and loyalty of parents in school institutions are getting better (Sari \& Nugroho, 2021). Meanwhile, according to Ernawati Shalihah, explaining that it is necessary to group and divide work into an organized organizational structure and establish an authority structure and coordination mechanism so that there are no mistakes in the implementation of parenting activities the implementation of parenting between one another.

The involvement of parents will be one of the determinants of the success of the program at school. Teachers as second educators must continue to establish good communication and relationships with parents to get the correct information about children to develop their children's potential to the maximum. Parents must also be actively involved in planning and implementing early childhood education in schools so that there is continuity and continuity of programs carried out by teachers at school and parents at home (Lestari, 2019).

Meanwhile, Anis Sulalah explains that, in implementing parenting events planned to run smoothly as desired, it is necessary to determine work methods and procedures so that the activity mechanism runs satisfactorily as expected. The organization carried out by Taman Posyandu Anak Salih forms an organizational structure, person in charge, class coordinator, and other division of tasks. The first step in organizing the parenting program at Taman Posyandu Anak Salih is to determine the target of parenting activities; after completion, it is determined who is in charge, but most of the large-scale parenting activities that are responsible are the school principal because those who are more closely related to the guardians of students is the head of the school So the principal can be said to be the liaison between the parents of the students and the school.

\section{Implementation of the Parenting Program}

Implementing the program so that it is carried out by parties within the organization and motivated to carry out responsibilities with full awareness and high productivity is part of the implementation process. As for the implementation and implementation, namely carrying out the process of leadership, mentoring, and providing work motivation to run effectively and efficiently to achieve organizational goals. Providing regular assignments and explanations about work and explaining the policies that have been set.

According to Mistria Harmonis, implementing the parenting program at Taman Posyandu Anak Salih is a large-scale parenting activity that includes seminar activities, and small-scale parenting includes small activities. For large-scale parenting, the teacher is the coordinator of the action. Meanwhile, small-scale parenthood delivers material regarding child development, child nutrition, and healthy socialization. The role of parents has been seen since the start of the new school year because the school invites parents to come to school to discuss learning activities and what needs the child needs. Physical needs and spiritual needs such as debriefing to face a new atmosphere for children to interact well with friends and teachers; this is also discussed in the parents' meeting. 
The benefits of parental involvement in children's education are increasing children's attendance, increasing children's confidence, improving children's positive behavior, growing children's developmental achievements, growing children's desire to go to school, improving communication between parents and children, increasing parent and child expectations, increasing trust (Mustajab \& Fawa'iedah, 2020). Parents increase parental satisfaction with school, improve teacher morale, support a better school climate, and support overall school progress (Elyana, 2020).

Meanwhile, Anis Sulalah, explained that this implementation is by the theory of the parenting program in the form of Parent Gathering, which is a meeting of parents with school institutions facilitated by the parenting program committee to discuss programs that have to do with guidance and care for children in the family to develop children optimally. The material in the meeting can be various things about the needs of children's growth and development, for example, nutrition and food, health, character education, diseases in children, and so on.

Parenting activities will be a forum that can benefit all parties, both parents, schools, and the government. There are several benefits in implementing parenting: (1) the establishment of cross-sectoral partners, for example, from entrepreneurs related to the development needs of children, government agencies, book publishers, and others, (2) fulfillment of children's rights needs. , (3) developing self-confidence of parents in educating children, (4) establishing a harmonious relationship with each family member according to their respective duties, (5) creating connections between families in the community around educational institutions, and (6) the establishment of working partners among fellow parenting members (Ariyati, 2016).

Meanwhile, Ernawati Shalihah, explains that at Taman Posyandu Anak Shalih every year always carries out a significant activity, namely Parenting. In this parenting activity, the school invites speakers from outside qualified in childcare; the participants in this seminar are parents, teachers, committees, and invitees. Parenting at Taman Posyandu Anak Salih always has a different theme every year; the teacher's internal meeting determines the article. The article is determined according to the needs of parents in shaping the child's character.

Apart from parenting activities, Taman Posyandu Anak Salih also has outbound activities that also involve parents and children. This activity is usually held in a tourist park or a place for student learning; this trains children's physical, motoric and social-emotional development as well as cooperation between children and parents; in addition to the activities above, the Shalih Children's Posyandu Park also has a peak theme activity or visit places that support learning activities. Teachers and children carry out visiting activities only without parents. For example, museum visits, stations, ports, or other areas match the learning theme. Exercises to train the cohesiveness of parents and children are not only in Outbound activities, but there are also Arts Festival activities where this festival is an activity that involves parents and children in competitions. The parenting event occurred at the taman posyandu salih children's hall can see at figure 3 .

\section{Parenting Program Evaluation}

Evaluation can be interpreted as a process to provide quality, namely the value of educational activities that have been carried out. The process takes place in a systematic, sustainable, planned, and carried out according to procedures. Mistria Harmonis, explains that, in implementing parenting activities, there needs to be an evaluation to be able to see the effectiveness of the program during implementation, to be able to revise the program if there are improvements required, and to be able to make the program an example of a successful program.

A parenting program is a form of activity in the form of support provided for parents to have the ability to carry out their social functions in terms of nurturing, caring for, protecting, and educating their children. This program hopes that future children can 
optimally grow and develop according to the stages of their developmental age and obtain good health and nutrition standards. The benefits from parenting programs are finding solutions through good interactive communication about child development and what rights parents must fulfill in the survival of their children (Fitroh \& Oktavianingsih, 2020). Meanwhile, Ernawati Shalihah, explained that, In parenting activities, schools must monitor activities, whether the activities have achieved the appropriate goals and objectives so that this activity can benefit all parties. Because parenting activities also impact the formation of children's character.

Every parent in educating children has a different character due to differences in educational, social, economic, and cultural backgrounds. This is a factor in the success of the participation in early childhood education. The factors that influence the role of parents in children's education include; a) social status factors are determined by elements such as education, occupation, and income; b) family form factor; c) the factor of the stage of family development starting from the occurrence of a marriage that unites two different individuals, followed by the stage of preparation to become parents; d) role model factors (Irma, Nisa, \& Sururiyah, 2019).

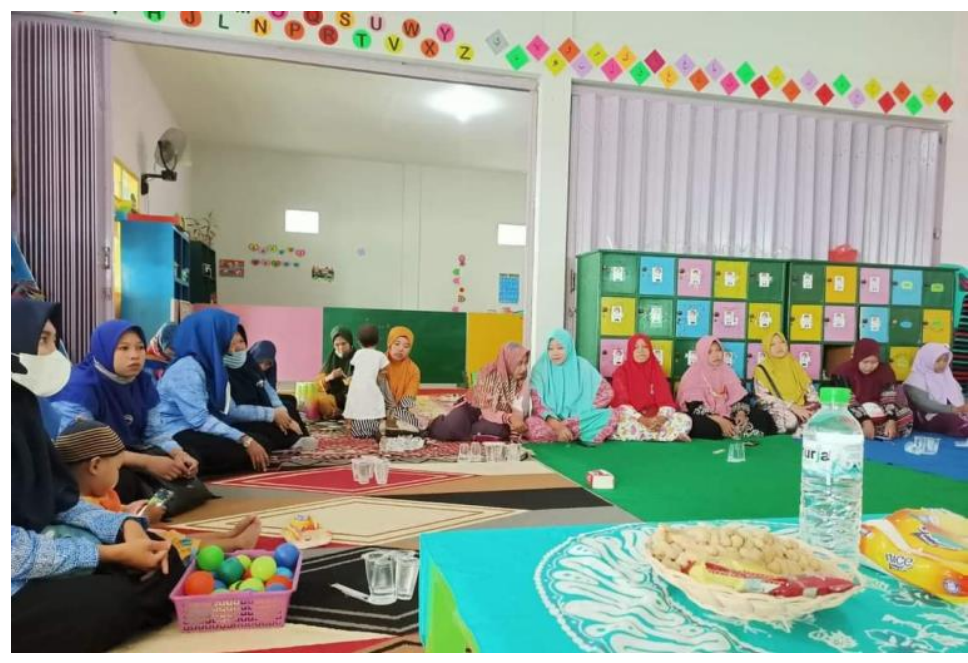

Figure 3 parenting program evaluation activities in the form of discussions and questions and answers

Meanwhile, according to Anis Sulalah, the activeness of parents during discussion sessions in the parenting program is also part of the evaluation process. In each discussion session, whether in parenting, the activeness of the father or mother in asking questions for discussion is very good. Because sometimes time runs out for debate, parents still want to ask questions. Meanwhile, according to Wardatul Lailiyah (2021), As the student's guardian revealed directly, the parenting program held by Taman Posyandu Anak Salih provides education for parents about the growth and development of children by their product. And not only that, with parenting, schools also provide education about parenting given to parents so that parents' knowledge increases about the formation of children's character. Meanwhile, according to Sri Wahyuni, as the student's guardian said that, with this parenting activity, we could learn together with other parents about children's growth and development and how to shape children's character, so that later the education that children get at home is by teaching. Obtained at school.

So evaluation form of parenting implementation at Taman Posyandu Anak Salih is carried out two times, namely at the end of the parenting program activities for parents in the form of discussions and questions and answers to find out how far the understanding of parents in receiving and understanding the material presented (Figure 3 ). While the evaluation of parenting program activities is carried out in a small meeting or discussion involving 
educators and managers, the review covers all program components and the entire process of implementing the parenting program. Evaluation is carried out to improve and improve the quality of the following program to be even better.

\section{CONCLUSION}

The formation of children's character requires a continuous and consistent process. Schools must build good cooperation with children's parents in the building and developing children's character. Creating integration between the nature of children at school with the feelings of children at home. So schools approach parents through parenting activities to become partners in children's education. So that parents can also maximize their role in the formation of children's character. With the management of parenting activities, schools can collaborate with families to form and develop a feeling for early childhood.

\section{ACKNOWLEDGMENT}

The researcher would like to thank the Rector of Nurul Jadid University, Paiton, Probolinggo, East Java, and Rector of Universitas Islam Negeri Sultan Aji Muhammad Idris, Samarinda, for providing motivation and support for this study. Hopefully, this research can provide benefits and inspiration for further researchers in developing learning innovations in schools.

\section{REFERENCES}

Afifah, M., Maulidi, A., \& Faza, N. (2021). Pembentukan Karakter Anak Usia Dini Melalui Pendidikan Parenting Di Sekolah. Irfani: Jurnal Pendidikan Islam, 17(1), 104-111.

Akhyadi, A. S., \& Mulyono, D. (2018). Program Parenting Dalam Meningkatkan Kualitas Pendidikan Keluarga. Jurnal Pengabdian Kepada Masyarakat (Abdimas) IKIP Siliwangi, 1(1), 1-8. https://doi.org/10.22460/as.v1i1p1-8.34

Alfina, A., \& Anwar, R. N. (2020). Manajemen Sekolah Ramah Anak Paud Inklusi. Al-Tanzim: Jurnal Manajemen Pendidikan Islam, 4(1), 36-47. https://doi.org/10.33650/altanzim.v4i1.975

Almuhajir, A. (2021). Controlling the Muhammadiyah Lhokseumawe Orphanage in Forming Independent Character of Foster Children. Al-Tanzim: Jurnal Manajemen Pendidikan Islam, 5(1), 176-189. https:// doi.org/10.33650/al-tanzim.v5i1.1962

Arif, D., \& Pratama, N. (2019). Tantangan Karakter di Era Revolusi Industri dalam Membentuk Kepribadian Muslim. Al-Tanzim: Jurnal Manajemen Pendidikan Islam, 3(1), 198-226. https://doi.org/10.33650/al-tanzim.v3i1.518

Ariyati, T. (2016). Parenting Di PAUD Sebagai Upaya Pendukung Tumbuh Kembang Anak Usia Dini. Jurnal Ilmiah Pendidikan, 9(2), 1-270.

Atika, Arifin, Z., \& Jannana, N. S. (2021). Integrated School Management-Character Education Affirmation: A Case Study in Muhammadiyah Wirobrajan 3 Elementary. Al-Tanzim: Jurnal Manajemen Pendidikan Islam, 5(2), 15-26. https://doi.org/10.33650/al-tanzim.v5i2.1970

Baharun, H. (2017). Total Moral Quality: A New Approach for Character Education in Pesantren. Ulumuna, 21(1), 57-80. https://doi.org/10.20414/ujis.v21i1.1167

Cahyono, H., Suhono, \& Khumairo, A. (2018). Pendidikan Karakter Bagi Pelaku Pedofilia (Sebuah Strategi Dalam Mengatasi Amoral). Jurnal Manajemen, Kepemimpinan, Dan Supervisi Pendidikan, 3(1), 1-19. https://doi.org/10.31851/jmksp.v3i1.1519

Elyana, L. (2020). Manajemen Parenting Class Melalui Media E-Learning. Sentra Cendekia, $1(1), 29-35$.

Nugrahani, F. (2017). Penggunaan bahasa dalam media sosial dan implikasinya terhadap karakter bangsa. Stilistika: Kajian Bahasa, Sastra, dan Pembelajarannya, 3(1). 
Fauzi, A., \& BR, R. (2018). Analysis Study of Parental Choice of Education in The Millenial Era. Nadwa: Jurnal Pendidikan Islam, 12(51), 311-330. https:// doi.org/10.21580/nw.2018.12.2.2904

Finori, F. D. (2019). Smart Techno Parenting: Alternatif Pendidikan Anak pada Era Tekhnologi Digital. Jurnal Tatsqif, 17(1), 52-69. https://doi.org/10.20414/jtq.v17i1.625

Fitroh, S. F., \& Oktavianingsih, E. (2020). Peran Parenting dalam Meningkatkan Literasi Kesehatan Ibu terhadap Stunting di Bangkalan Madura. Jurnal Obsesi: Jurnal Pendidikan Anak Usia Dini, 4(2), 610-619. https:// doi.org/10.31004/obsesi.v4i2.415

Gultom, A. L., Saparahayuningsih, S., \& Suprapti, A. (2021). Faktor-Faktor Penghambat Pelaksanaan Kegiatan Parenting Di PAUD/TK Dharmawanita Persatuan Kota Bengkulu. Jurnal PENA PAUD, 2(1), 1-17.

Iltiqoiyah, L. (2020). Manajemen Pembelajaran melalui Pendekatan BCCT dalam Meningkatkan Multiple intelligences Anak. Jurnal Obsesi : Jurnal Pendidikan Anak Usia Dini, 5(2), 1368-1381. https://doi.org/10.31004/obsesi.v5i2.781

Indarawati. (2021). Program Parenting Dalam Meningkatkan Pemahaman Masyarakat Terhadap Tumbuh Kembang Anak Usia Dini. KREASI: Jurnal Pengabdian Masyarakat, $1(1), 21-24$.

Irma, C. N., Nisa, K., \& Sururiyah, S. K. (2019). Keterlibatan Orang Tua dalam Pendidikan Anak Usia Dini di TK Masyithoh 1 Purworejo. Jurnal Obsesi : Jurnal Pendidikan Anak Usia Dini, 3(1), 214-224. https:// doi.org/10.31004/obsesi.v3i1.152

Jennah, M. (2019). Smart Parenting dalam Mengatasi Social Withdrawal pada Anak di Pondok $\begin{array}{lllll}\text { Pesantren. Ta'allum: Jurnal Pendidikan } & \text { Islam, }\end{array}$ https:// doi.org/10.21274/taalum.2019.7.1.45-72

Junita, E. N., \& Anhusadar, L. (2021). Parenting Dalam Meningkatkan Perkembangan Perilaku Sosial Anak Usia 5-6 Tahun. Yaa Bunayya : Jurnal Pendidikan Anak Usia Dini, 5(2), 57 63.

Lailiyah, W. (2021). Interview. Turkish Journal of Diaspora Studies, Vol. 1. https:// doi.org/10.52241/TJDS.2021.0010

Lestari, N. G. A. M. Y. (2019). Program Parenting Untuk Menumbuhkan Kesadaran Pentingnya Keterlibatan Orangtua di PAUD. Pratama Widya: Jurnal Pendidikan Anak Usia Dini, 4(1), 8-17. https://doi.org/10.25078/pw.v4i1.1064

Mahmudah. (2018). Konstruksi Pendidikan Karakter di Madrasah Berbasis Pesantren. Jurnal Mudarrisuna, 8(1), 153.

Maryam, S. (2018). Building Character Education Using Three Matra of Hasan Al-Banna'S Perspective in Pesantren. Jurnal Pendidikan Islam, 4(2), 51-62. https://doi.org/10.15575/jpi.v4i2.2422

Muali, C., Rofiki, M., \& Sholeh, L. (2021). The Role of Sufistic-Based Kiai Leadership in Developing the Character of Santri in the Pesantren. AL-ISHLAH: Jurnal Pendidikan, 13(3), 1705-1714. https:// doi.org/10.35445/alishlah.v13i3.1012

Mundiri, A., \& Jannah, F. (2021). Quality Assurance of Education in Senior High School during Covid-19 Pandemic. Al-Ishlah: Jurnal Pendidikan, 13(3), 2203-2212. https://doi.org/10.35445/alishlah.v13i3.1190

Munif, M., Rozi, F., Yusrohlana, S., \& Jadid, U. N. (2021). Strategi Guru Dalam Membentuk Karakter Siswa Melalui Nilai-Nilai Kejujuran. Fondatia: Jurnal Pendidikan Dasar, 5(September), 163-179. https:// doi.org/10.36088/fondatia.v5i2.1409

Mustajab, M., \& Fawa'iedah, Z. (2020). Adapting to Teaching and Learning During Covid-19: A Case of Islamic School's Initiative of Self-regulated Learning. Nadwa, 14(2), 241-264. https://doi.org/10.21580/nw.2020.14.2.6515

Nurmiyanti, L., \& Candra, B. Y. (2019). Kepemimpinan Transformasional dalam Peningkatan Mutu Pendidikan Anak Usia Dini. Al-Tanzim: Jurnal Manajemen Pendidikan Islam, 3(2), 13-24. https://doi.org/10.33650/al-tanzim.v3i2.646 
DOI: 10.31004/obsesi.v6i4.2065

Perpres. (2013). Peraturan Presiden Republik Indonesia Nomor 60 Tahun 2013. Gospodarka Materiałowa I Logistyka, 26(4), 185-197.

Prasanti, D., \& Fitrianti, D. R. (2018). Pembentukan Karakter Anak Usia Dini: Keluarga, Sekolah, Dan Komunitas. Jurnal Obsesi : Jurnal Pendidikan Anak Usia Dini, 2(1), 1319. https:// doi.org/10.31004/obsesi.v2i1.2

Rahma, R. A., Sucipto, Rasyad, A., Listyaningrum, R. A., Puspitasari, S. W., \& Ghozwatul, R. (2021). Pembinaan Guru Pendidik Anak Usia Dini Dalam Penyelenggaraan Program Parenting Education. Abdimas Pedagogi: Jurnal Ilmiah Pengabdian Kepada Masyarakat, 4(2), 97-104.

Ramdhani, S., Yuliastri, N. A., Sari, S. D., \& Hasriah, S. (2019). Penanaman Nilai-Nilai Karakter melalui Kegiatan Storytelling dengan Menggunakan Cerita Rakyat Sasak pada Anak Usia Dini. Jurnal Obsesi: Jurnal Pendidikan Anak Usia Dini, 3(1), 153-160. https://doi.org/10.31004/obsesi.v3i1.108

Rozi, F., \& Maulidiya, H. (2022). The â€TM Sekolah Sak Ngajine â€TM Program ; The Habit of loving the Qur â€TM an from an Early Age based on Tilawati. Jurnal Obsesi : Jurnal Pendidikan Anak Usia 1667-1676. https://doi.org/10.31004/obsesi.v6i3.1636

Sari, D. N., \& Nugroho, R. (2021). Kepuasan Orang Tua Pada Program Parenting Dalam Jaringan Di Paud Khadijah Wonorejo. J+PLUS UNESA; Jurnal Mahasiswa Pendidikan Luar Sekolah, 10(1), 121-133.

Suharyani, Suarti, N. K. A., Tamba, I. W., Gunawan, I. M., \& Astuti, F. H. (2021). Implementasi Program Parenting bagi Orang Tua Siswa di PAUD Al-Akram Desa Sepapan Kabupaten Lombok Timur. Jurnal Pengabdian UNDIKMA, 2(1), 83-90. https://doi.org/10.33394/jpu.v2i1.3729

Tanto, O. D., Hapidin, H., \& Supena, A. (2019). Penanaman Karakter Anak Usia Dini dalam Kesenian Tradisional Tatah Sungging. Jurnal Obsesi : Jurnal Pendidikan Anak Usia Dini, 3(2), 337-345. https://doi.org/10.31004/obsesi.v3i2.192

Umiarso, \& Hidayati, N. (2022). Improving Children â€TM s Cognitive Intelligence Through Literacy Management. Jurnal Obsesi: Jurnal Pendidikan Anak Usia Dini, 6(3), 15881598. https:// doi.org/10.31004/obsesi.v6i3.1817

Ummah, R. (2018). Strengthening Student's Character in Akhlaq Subject Through Problem Based Learning Model. Tadris: Jurnal Keguruan Dan Ilmu Tarbiyah, 3(1), 21-30. https://doi.org/10.24042/tadris.v3i1.2205

Zamroni, Amir, \& Saleha, L. (2021). Pengelolaan APE Berbahan Limbah untuk Meningkatkan Kecerdasan Kognitif Anak. Jurnal Obsesi: Jurnal Pendidikan Anak Usia Dini, 5(2), 1382-1395. https://doi.org/10.31004/obsesi.v5i2.763

Zulfaizah. (2018). Revitalisasi Pendidikan Agama dalam Pembentukan Karakter Peserta Didik di Madrasah. Elementary, 6(1), 43-62. 